\title{
SOCIAL RESPONSIBILITY, SUSTAINABILITY AND MICRO-ENTERPRISES: CONTRIBUTIONS MADE BY A MICRO-ENTERPRISE
}

This article presents the experience of a small environmental consultancy company when adopting the concept of Social Responsibility. The goal is to encourage other businesses to accept the challenge of overcoming social and environmental problems to build sustainable societies. We will show how companies, even small ones, can work with transparency, valuing employees and staff, improving its environment continually, bringing together partners and suppliers, protecting consumers, promoting its community, and committing to the common good. The company mentioned in this article achieved these purposes by building, social bridges' among institutions of various fields and locations in the metropolitan region of Rio de Janeiro.Gênesis Environmental Education Centre is a consultancy firm whose mission is to educate about sustainability, through environmental education activities, aimed at various segments of society. It was created in 2005 and is located in Tenente Elias Magalhães street, 140, Colubandê, São Gonçalo, in an area of ecological interest due to the existence of threatened species, the Atlantic forest, streams and a spring. Gênesis Centre is always concerned about environmental issues and, since its implementation, it has conducted activities aimed at schools, businesses, and religious institutions. The main activities are training courses, workshops, development and implementation of projects, environmental education, and nature trails. The Centre promotes education for sustainability through the concept of Social Responsibility, applied as a guiding principle for all activities and networks. The company follows guidelines organized by Ethos Institute regarding Social Responsibility.

Key words: companies, social responsibility, sustainability

Lourdes Brazil dos Santos Argueta, Phd, Federal Fluminense Unversity, Brasil. e-mail: ourdesbrazils@gmail.com

** Cristiane de Barros Pereira, Environmental Centre Gênesis, e-mail: crisbarpe@bol.com.br Vol. 11, No 3, 2014: 123-134 


\section{Introduction}

This article was developed based on partial results of a research that has been carried out in the metropolitan region of Rio de Janeiro (RMRJ) since 2010. We aim to investigate how Brazil has faced the challenges of overcoming unsustainable urban spaces and building sustainable cities. Results showed that Brazil has adopted strategies that include the elaboration of documents, and planning of actions to be performed by participants, such as universities, companies, and NGOs. This article presents the experience of a micro-enterprise in the field of environmental consultancy. We emphasize the adoption of the Social Responsibility concept in partnership with several institutions, particularly Universidade Federal Fluminense (UFF). Our purpose is to show that even small companies can adopt values and work with transparency. Any enterprise should value employees, improve its work environment, invest in networking, protect costumers, help community, and commit to the common good. We aim to motivate other small companies to participate in the challenge of overcoming socio environmental problems and building sustainable societies. To achieve this goal, we will not only explain the process, but also present contributions made by the university so that new companies can feel interested in participating, via university extension.

According to Correa (2013) 'extension' is defined as an educational, cultural and scientific process that brings together teaching and research inseparably, enabling a transforming relationship between university and society. Extension in public universities is systematized in the following thematic areas: Communication, Culture, Human Rights and Justice, Education, Environment, Health, Technology and Production, and Work.

Each thematic area is developed following defined programmatic lines where interdisciplinarity is stimulated, which foresees the existence of thematic interfaces and interactions. Special emphasis is given to the participation of university sectors of extension in the preparation and promoting of public policies. These policies aim to assist the population, improve education and public services, and open up new processes of production, innovation and knowledge transfer. Thus, access to knowledge is facilitated, contributing to the technological and social development of the country.

Universidade Federal Fluminense is located in Niterói, Rio de Janeiro. Like most of Brazilian universities, UFF kept apart from social issues. This situation started changing in the '90s, when teachers began to approach the community by developing activities in the area of education and health. In 1999, the National Plan of Extension (PNE) was signed, promoting these activities. Currently, they are performed in several places, following the guides established by PNE:

Impact and transformation: Establishment of a relationship between universities and other sectors of society aiming at transforming performance. This 
performance should focus on the interests and needs of the majority of the population. It should also create public and regional development policies.

Dialogic Interaction: Establishment of a dialogue between universities and social sectors enabling two-way actions, and exchange of knowledge. Thus, the speech of academic hegemony can be overcome, enabling partnerships with social movements to surmount inequalities and exclusion.

Interdisciplinarity: Interaction of models, complementary concepts, analytical material and methodologies, seeking theoretical and operational consistency. It aims to structure the performance of participants in the social process and enable the interaction among organizations, professionals, and people.

Education - Research - Extension: Every action related to extension must be linked to the education process and the production of knowledge. Students must assume their role as main agents in their technical training, not only to learn required skills, but also to become conscious professionals and citizens. Thus, they recognize themselves as responsible for their rights and responsibilities, adopting a transforming view towards society.

These guidelines helped universities assume their institutional role in the solving of problems in partnership with other sectors of society. Universities approached members of health, transportation, and housing forums; groups representing gender, ethnicity, and environmental issues; and campaigns for underprivileged groups, such children, adolescents, and the elderly.

It is worth mentioning that universities showed their commitment during a remarkable moment in the Brazilian scenario: the increase of peripheral areas in the urban centres, due to the growing poor population in the cities and big metropolises. Of a population of nearly 33 million poor, 35\% were in cities and $41 \%$ in metropolises. Currently, Brazilian cities have gone through transformations caused by the inclusion of Rio de Janeiro, São Paulo, and Brasília in the context of global cities. This insertion creates new urban territoriality, frequently deepening spatial segregation. (Santos, 2005).

\section{Social responsibility}

During the 1980s, Brazilian companies began to recognize the importance of adopting practices of Social Responsibility. This recognition was enabled by the approach between private sectors and social movements. The sociologist Herbert de Souza, known as Betinho, launched the national campaign Citizens' Action against Hunger, Poverty and for Life, counting on the institution Pensamento Nacional das Bases Empresariais (PNBE) as a supporter [PNBE is a noncorporative business entity that fights for the interests of the population]. In the 1990s, non-governmental organizations help to consolidate practices of Social

Vol. 11, No 3, 2014: 123-134 
Responsibility. Among these organizations, IBASE stands out for the dissemination of the social accounting process and the creation of ETHOS Institute.

Social Responsibility is the obligation a company has to participate in the process of overcoming socio-environmental problems through actions, as Chiavenato says:

"Social Responsibility is the level of obligations an organization has to take actions to protect and improve the well-being of society as it seeks to achieve its own interests". (Chiavenato, 2004, p. 119)

Social Responsibility can be one of the paths to be followed to promote sustainability. Currently, several companies have adopted the concept. In this process, six stages are identified according Garcia (2006).

STAGE 1: The organization does not assume responsibilities towards society and does not take actions to favour responsible citizenship. There is no promotion of ethical behaviour.

STAGE 2: The organization presents some isolated actions to minimize problems, recognizing the impacts caused by its products, processes and facilities. Occasionally, it promotes ethical behaviour.

STAGE 3: The organization begins to elaborate processes to assess the impacts of its products, process, and facilities. It also demonstrates some leadership dealing with important issues to the community. People get involved in efforts for social development.

STAGE 4: The process of assessing the impacts of products, processes and facilities is in phase of systematization. The organization demonstrates leadership in important issues to the community in various ways. Frequently, people get involved in efforts for social development. The organization promotes ethical development.

STAGE 5: The process of assessing the impact of products, processes and facilities is systematized, enabling the prediction of public problems. The organization leads issues of interest to the community and the industry. The company systematically motivates people to get involved in efforts for social development. There are implemented methods to evaluate and improve the performance of the organization in the exercise of responsible citizenship, and in the treatment of its public responsibilities.

Large companies are at this last stage. They conduct projects in the communities where they are located. These companies focus on themes related to the needs of the community and its routine, like the training of workforce and the fight against violence, through projects to create jobs and income. Small companies are at stage 1 and 2. 


\subsection{Micro-enterprises and Social Responsibility: Gênesis Centre}

According to Sebrae-SP, there are 5.1 million companies in Brazil. Of this total, $98 \%$ are micro and small businesses (MPEs). Small businesses (formal and informal) account for more than two-thirds of industry occupations. These firms are fundamental in promoting economic growth, generating jobs and income, and improving quality of life. Their contributions are acknowledged mainly because of the the exposition enabled by this type of business, and the employment of workforce, including those who has difficulties to participate in the labour market, like young people seeking their first job and people over 40 . Small companies give dynamism to the economy of cities and neighbourhoods. Recent data from IBGE inform that MPEs represent 20\% of the Brazilian GDP. Additionally, they are responsible for $60 \%$ of 94 millions of jobs in the country, and represent $99 \%$ of 6 millions of formal business in Brazil.

The participation of MPEs in the total of profitable business in Brazil has increased. While businesses, regardless their size, had an annual total of $4 \%$ growth, small firms grew $6.2 \%$, and micro ones 3,8\%, between 2000 and 2008 . In the same period, MPEs were responsible for nearly half of the total of formal jobs generated, that is, 4.5 million jobs.

The concept of Social Responsibility has been adopted on a slow path, because companies lack resources to be employed in activities that are not directly related to its business processes. Additionally, most of the time these companies do not present enough knowledge in management to improve results. FIRJAN and ETHOS Institute elaborated a step-by-step plan to motivate micro and small firms to adopt the concept. Gênesis Centre used this guide for its activities. This centre works as a consultancy company whose mission is to offer programmes and projects to its customers. The aim is to promote education for sustainability, thus contributing to create autonomous and critical individuals with ethical values.

It also helps to create participative, transparent and fair institutions; to involve communities in collective interests towards tolerance and equity; to encourage environmental practices that preserve biodiversity and develop ecological processes to sustain life. Gênesis Centre has a sustainability council, formed by masters and PhDs from Brazil and abroad responsible for building a sustainability policy.

It was created in 2005 and is located in Tenente Elias Magalhães street, 140, Colubandê, São Gonçalo (a city from the metropolitan region of Rio de Janeiro). The territory of São Gonçalo has $248,72 \mathrm{~km}$, thus corresponding to $4.4 \%$ of the metropolitan region. According to statistics from the 2000 census, the city has approximately 1 million inhabitants with a population density of $3.577,9$ people per $\mathrm{Km}$. The main access is by BR 101 and RJ 104, which faces the city of Nite- 
rói, to the south, and Itaboraí, to the north. São Gonçalo has 90 neighborhoods distributed in 5 districts: São Gonçalo, Ipiiba, Monjolos, Neves and Sete Pontes.

The neighbourhood of Colubandê has about 95,000 inhabitants and is located in the headquarter district of São Gonçalo. It presents 3 different areas:

Central Area - The most valued area where most services, companies, and markets are located.

Historic Area - It is located along RJ 104 highway, and is considered historic because the neighbourhood derived from it. An important milestone in this place is Colubandê Farm, where the Forestal Battalion is currently located.

Intermediate Area - between the end of Salvatori (Makro and CCPl) and the borders of Rocha neighbourhood. This area is integrated by Água Mineral sub-neighbourhood, formed by several lots demarcated in the ' 50 s and ' 60 s. This area had a relevant importance in São Gonçalo from 1940 to 1960 because of a company of mineral water. The closure of the factory caused a significant decline in the area. The situation worsened in the following years due to violence, especially coming from ,extermination groups. Even nowadays, the whole area suffers the stigma of being a violent local.

Genesis Centre is located in this area and develops projects to assist schools, companies, and religious institutions. The principal activities are training courses, workshops, environmental education, and environmental trails. The company has four employees, three of them live in the community. Like most of the locals, they quit school early and entered the labour market. However, all of them are encouraged to return to school, and take training courses to become qualified professionals.

Since its beginning, Gênesis Centre has socio-environmental issues as one of its main concerns. The focus is on Social Responsibility, because it promotes education for sustainability. Very early directors noticed that it would be very important to employ this concept in all activities and networks. For this reason, the strategy of Social Bridges ${ }^{1}$ was adopted. The partnership with UFF was established through the integrated program of research and extension Underprivileged Urban Childhoods, Environmental Education and Sustainability, and through the research group HIDROUFF.

The company follows guidelines organized by Ethos Institute: Adoption of values; work with transparency; valuing employees and collaborators; continual improvement of the environment; involvement of partners and suppliers; protection of customers and consumers; promoting the community; and commitment to the common good. Of these items, only the protection of customers has not been dealt yet.

Gênesis' mission requires commitment to socio-environmental issues regarding the community, the city, the region, and the planet. It also aims at the building of sustainability. We follow an expanded and progressive conception of

It is the union between companies aiming to seek solutions for social demands. 
sustainability. The first concept considers sustainability a pragmatical process of sustainable development. The second introduces new dimensions that provide an understanding that goes beyond economic and environmental issues. Thus, sustainability can be thought according to specificities of each country or region. In Brazil, this last concept helps us think about sustainability from an ethnic and racial point of view, considering inequalities experienced by the afro-descendant population. We work with the following main dimensions:

Environmental Sustainability: It refers to the capacity of the environment to absorb aggressions caused by human actions, or recover from them. It also seeks a balance between emission rates and/or production of residues, and absorption rates and/or regeneration of natural resources.

Ecological Sustainability: It refers to the physical base of the growth process and aims at the preservation and the conscious use of supplies of natural resources.

Cultural Sustainability - It is the need to support cultural diversity and practices existing in different regions of the world. These practices build the identity of nations.

Social Sustainability - It aims to improve quality of life, reduce social exclusion rates, through public policies related to redistributive justice.

Political Sustainability - It refers to the building of full responsible citizenship for individuals through the strengthening of democratic devices to formulate and implement public policies on a global scale. It also refers to government and governance on a local, national, and global scale.

Institutional Sustainability - It aims to design and strengthen engineering courses that take into account criteria related to sustainability.

\section{Geênesis centre and the University}

Genesis Centre participates in extension activities of the programme Underprivileged Urban Childhoods, Environmental Education and Sustainability, and also of the research group HIDROUFF, line of research Environment, Sustainability and Social Responsibility.

Prior to the implementation of Gênesis Environmental Education Centre, Colubandê neighbourhood was degraded due to sand and wood extraction, to produce coal, and frequent forest fire. There was also hunting for small animals and felling of trees for construction. Due to degradation, many plant species died out and a fountain virtually dried up. The main environmental problems of Colubandê are social curtailment of children and adolescents, pollution caused by garbage, and destruction of biodiversity. 


\subsection{The social curtailment of children.}

It refers to limitations on the formation of children's human capital. This concept is used in Economics to refer to a stock of skills that begins to be built in childhood and adolescence. Each individual will accumulate the amount of skills equivalent to his/ her inborn talents, private and public resources. (Barros and Mendonca, 1995)

The authors suggest three situations in which the accumulation can occur: existence of private and public resources, existence of public resources, and inexistence of public and private resources.

Segregated spaces, like Colubandê, belong to the third group: their population cannot afford educational and cultural services. To make things worse, government do not provide these services in a satisfying way, either in quantity or in quality. Schools are examples of inefficient service offered by governments. In many cases, constructions are precarious: small rooms, low ceilings, bathrooms in bad conditions, and ugly architecture.

Although some segregated neighbourhoods are near places that offer various services, their residents do not have access to them. It happens because residents from segregated neighbourhoods are not aware of the existence of these services, or are denied access to them. There are some concrete impediments: lack of sufficient resources to commute to other places, lack of company, or symbolic reasons.

The insufficient provision of educational and cultural services compromise children's human capital. This capital could offer qualified work force in the future, and could also offer the young better salaries. Instead, these teenagers will probably get low paid jobs that require poor qualification. Thus, they will be fated to stay at the same social and physical environment they were raised, as Bordieu confirms (1997):

"... those who do not have a good financial condition [and do not receive investments] are kept apart, physically or symbolically, from rare social wealth and condemned to live with undesirable, and less rare, wealth and people. The lack of investment intensifies the experience of finitude: it attaches the individual in one place". (Bordieu, 1997, p. 26)

We noticed that a precarious environment can cause a feeling of indignity, which is expressed through violence, making the individual lose opportunities in the place he/she lives, mainly at school. That is why we develop activities to improve self-esteem and to fight the social curtailment of children. The media is frequently reporting violent acts commited by children and adolescents from Colubandê at home, in the community, at school, and parties. That is the only situation in which these individuals are given prominence. Our strategy was to 
give them visibility because of positive attitudes, exposing materials produced by these children and teenagers: texts containing protest messages organized in small books and posters. These books were published and have been used as teaching material in schools. Some texts were translated into French and presented at a panel discussion about urban childhoods in Brazil and in France, at Aliança Francesa (a French course in Niterói), as part of celebrations of the International Year of France in Brazil. Additionally, these children and adolescents participated in a video-clip that has been broadcast in several countries including Germany, which is using it at schools.

\subsection{Environmental Pollution caused by garbage.}

Although there is regular garbage collection, part of the population through garbage in derelict lands, and into the river that crosses the neighbourhood. Thus, garbage is always present in the landscape of Colubandê. The river, once used for leisure, is now polluted with plastic bottles and sewage. When there is heavy rain, the river overflows its banks and goes into nearby houses. Lands that could be used as sport courts or even squares are full of garbage, disseminating diseases and degrading the landscape. The campaign E se não tivesse Lixo? (If no garbage existed?) was created to face this situation. The initiative counted on the participation of children from 3 schools of the neighbourhood and was conducted with lectures, groups of discussion, production and distribution of materials. As a result, the amount of garbage had a significant reduction in the neighbourhood and schools.

\subsection{Destruction of biodiversity.}

Colubandê presents a framework of degradation due to the extraction of sand and wood, for coal production, and frequent forest fire. There was also hunting for small animals and felling of trees for construction. Most of the population, especially the young, participated in the process of degradation, because they were unaware of the ecological, environmental, and historic importance of the area. Due to degradation, many plant species died out and the fountain virtually dried up.

With the implementation of Gênesis Centre, however, this situation changed, and there is no more hunting either sand extraction. Only forest fires remain, because many of them are caused by hot-air balloons. A campaign was organized in 2010 to encourage children to plant trees, using seedlings and seeds distributed by Gênesis Centre.

Besides these actions, many others have been developed. This is only possible through the establishment of partnerships, as showned in the following table. 
Table 1: Summary table of activities

\begin{tabular}{|l|l|}
\hline GUIDELINE & ACTIONS AND PARTNERS \\
\hline Adoption of values and transparency & Choice of mission aligned with sustainability \\
\hline Valuing employees & Encouraging the return to school \\
\cline { 2 - 3 } & Opportunity for training in the environmental area \\
\hline Actions in favour of the environment & Campaigns about garbage \\
\cline { 2 - 3 } & Universidade Federal Fluminense \\
\cline { 2 - 3 } & Faculdade Batista of Rio de Janeiro \\
\cline { 2 - 2 } & Campaign about water \\
\cline { 2 - 2 } & Universidade Federal Fluminense \\
\hline & Faculdade Batista of Rio de Janeiro \\
\cline { 2 - 3 } & $\begin{array}{l}\text { Campaign to encourage the planting of trees in the } \\
\text { community }\end{array}$ \\
\cline { 2 - 3 } & Universidade Federal Fluminense \\
\cline { 2 - 3 } & Faculdade Batista of Rio de Janeiro \\
\cline { 2 - 3 } & Evangelical institutions \\
\cline { 2 - 3 } & $\begin{array}{l}\text { Distribution of seedlings and seeds for the metropolitan } \\
\text { region of Rio de Janeiro }\end{array}$ \\
\cline { 2 - 3 } & Makro supermaket chain \\
\cline { 2 - 3 } & Municipal plant nursery \\
\hline Promoting the community & Projects for children \\
\cline { 2 - 3 } & Universidade Federal Fluminense \\
\hline
\end{tabular}

\section{Conclusions}

Results achieved by these activities show that micro-enterprises can develop activities aligned with Social Responsibility concepts, contributing to the building of sustainability. The lack of technical staff and financial resources can be supplied with partnerships with companies of various areas. Each one of them can contribute providing dissemination channels, financial resources, qualified personnel, and information on the topics to be treated. Like Gênesis Centre, other small companies can establish partnerships with universities to empower their actions. Research shows that many small and micro-enterprises are located in suburban neighbourhoods of large cities, places that present a series of problems regarding socio-environmental issues. The social curtailment of children and adolescents is one of the most urgent problems to be tackled. Activities like projects and courses can help children to overcome vulnerabilities and become propagators of sustainability. 


\section{Literature}

- Bourdie, P. (1997). A Miséria do mundo.

- Corrêa, E.J. (2013). Extensão universitária, política institucional e inclusão social. Revista Brasileira de Extensão Universitária, 1, 12-15.

- Chiavenato, I. (2004). Introdução à teoria geral da administração. Elsevier.

- De Barros, R.P. and de Mendonça, R.S.P. (1995). Os determinantes da desigualdade no Brasil. Ipea.

- Santos, M. (2005). A urbanização brasileira, 6. Edusp.

- Garcia, B.G. (2006). Responsabilidade social das empresas: a contribuição das universidades, 3 . Editora Peirópolis. 


\author{
Prof. dr Lourdes Brazil dos Santos Argueta, \\ Federalni „Fluminense“ univerzitet, Brazil \\ Cristiane de Barros Pereira, \\ Centar za životnu sredinu „Genesis“
}

\title{
DRUŠTVENA ODGOVORNOST, ODRŽIVOST I MIKRO-PREDUZEĆA: DOPRINOSI JEDNOG MIKRO-PREDUZEĆA
}

\section{S a ž e t a k}

Članak predstavlja iskustvo jedne male konsultantske firme za ekologiju prilikom usvajanja koncepta socijalne odgovornosti. Cilj je da se da podstrek drugim firmama da prihvate izazov u prevazilaženju socijalnih i ekoloških problema ka izgradnji održivih društava.U radu je pokazano kako firme, čak i male, mogu raditi transparentno, ceneći svoje zaposlene i drugo osoblje, stalno unapređujući svoje ekološko okruženje, zbližavajući svoje partnere i dobavljače, štiteći potrošače, promovišući svoju zajednicu i opredeljujući se za opšte dobro. Firma koja je u ovom članku pomenuta uspela je da izgradi ove principe gradeći takozvane „društvene mostove" između institucija različitih namena i lokacija u širem području Rio de Žaneira. Genesis Environmental Education Centre je konsultantska firma čiji je cilj da obrazuje u polju održivosti, kroz obrazovne aktivnosti o ekologiji, a namenjene raznim segmentima društva. Formirana je 2005. g. i nalazi se u ul. Tenente Elias Magalhaes 140, Kolubande, Sao Gonkalo, u ekološki interesantnom kraju gde postoje ugrožene vrste, Atlantska šuma, potoci i izvor. Genesis centar se bavi ekološkim pitanjima, i od nastanka su izveli aktivnosti usmerene ka školama, firmama i verskim institucijama. Osnovne aktivnosti su obrazovni kursevi, radionice, razvoj i implementacija projekata, obrazovanja o ekologiji i specijalno razvijeni puteljci kroz prirodu. Centar promoviše obrazovanje za održivost kroz koncept „Socijalne odgovornosti“, držeći se tog principa u svim aktivnostima i mrežama. Firma se drži smernica organizovana od strane Instituta Ethos, o Socijalnoj odgovornosti.

Ključne reči: firme, društvena odgovornost, održivost 